\title{
Modern chronic heart failure therapy in context of pulmonary banding to avoid heart transplantation
}

S Recla,,$\underline{\text { Aff1 }}$

Corresponding Affiliation: Aff1

B Steinbrenner, $\stackrel{\text { Aff1 }}{\text { a }}$

T Logeswaran, Aff1

L Rüblinger,, Aff1

D Schmidt, $\stackrel{\text { Aff1 }}{,}$

J Bauer, $\stackrel{\text { Aff1 }}{ }$

C Apitz, $\stackrel{\text { Aff1 }}{ }$

J Thul,,$\stackrel{\text { Affl }}{ }$

D Schranz,, Aff1

\begin{tabular}{|c|c|c|}
\hline \multicolumn{3}{|r|}{ ArticleInfo } \\
\hline ArticleID & $:$ & 56 \\
\hline ArticleDOI & $:$ & 10.1186/2194-7791-2-S1-A16 \\
\hline ArticleCitationID & $:$ & A16 \\
\hline ArticleSequenceNumber & $:$ & 16 \\
\hline ArticleCategory & $:$ & Meeting abstract \\
\hline ArticleFirstPage & $:$ & 1 \\
\hline ArticleLastPage & $:$ & 2 \\
\hline ArticleHistory & $:$ & $\begin{array}{ll}\text { RegistrationDate } & : 2015-7-1 \\
\text { OnlineDate } & : 2015-7-1\end{array}$ \\
\hline ArticleCopyright & $:$ & $\begin{array}{l}\text { Recla et al.2015 } \\
\text { This article is published under license to BioMed Central } \\
\text { Ltd. This is an Open Access article distributed under the } \\
\text { terms of the Creative Commons Attribution License } \\
\text { (http://creativecommons.org/licenses/by/4.0), which permits } \\
\text { unrestricted use, distribution, and reproduction in any } \\
\text { medium, provided the original work is properly cited. }\end{array}$ \\
\hline
\end{tabular}

Aff1

Children's Cardiology Center at, Giessen University Hospital, Germany 
Abstracts of the 51st Workshop for Pediatric Research

51st Workshop for Pediatric Research

Göttingen, Germany

16-17 April 2015

This supplement has not been sponsored.

Meeting abstracts

\section{Background}

Dilated cardiomyopathy (DCM) is a leading cause of cardiac death in children. Approximately $30 \%$ of children die or need cardiac transplantation in the first year after diagnosis. We established a protocol to improve the outcome in this high-risk population.

\section{Patients and methods}

We present our experience in 21 patients (mean age 8 month, mean weight $6 \mathrm{~kg}$ ) treated in our institution from 2006 to 2015. The patients were diagnosed with DCM with a highly impaired function of the LV (mean EF 17\%) and a conserved function of the RV (mean EF 52\%). Our protocol for medical enhancement of left ventricular recovery in association with pulmonary artery banding involves the use of a highly specific $\beta_{1}$-blocker, an angiotensin-converting enzyme inhibitor and an aldosterone antagonist. Our therapy aims to reduce oxygen consumption and improve oxygen delivery. Heart rate control is the most important goal; therefore clonidine is given after surgical procedure and digoxin in long-term treatment if heart rate remains high despite adequate $\beta_{1}$-blocker therapy. To improve oxygen delivery our goal is to archive haemoglobin levels of $12-14 \mathrm{~g} / \mathrm{dl}$, therefore Erythropoietin is given as long term treatment. Additional treatments include supplementation of carnitine, coenzyme Q, riboflavin or thiamine.

\section{Results}

At a mean follow up of 36 month (range 2-120) freedom from death was $91 \%$ and freedom from heart transplantation was $85 \%$. Surviving patients showed a significant improvement in left ventricular ejection fraction (from $17 \pm 6$ to $50 \pm 11 \%$ ) and LVEdD (z-score from $+7 \pm 2$ to $+1.7 \pm 1.9$ ). The levels of BNP improved significantly (from $3222 \pm 2756$ to $70 \pm 56 \mathrm{pg} / \mathrm{ml}$ ).

\section{Conclusion}

Our data suggest that the medical and surgical approach described may result in a markedly improved medium-term outcome in children with DCM. Further studies are required to evaluate the long-term-outcome of these patients. 